\title{
Post-Soviet Civil Society in Transition: Leftist Social Movements in Lithuania
}

\author{
Laura Dauksaite ${ }^{1 *}$
}

\author{
${ }^{1}$ Central European University, Vienna, AUSTRIA
}

*Corresponding Author: dauksaite_laura@alumni.ceu.edu

Citation: Dauksaite, L. (2021). Post-Soviet Civil Society in Transition: Leftist Social Movements in Lithuania, Journal of Cultural Analysis and Social Change, 6(1), 04. https://doi.org/10.20897/jcasc/11121

Published: July 31, 2021

\begin{abstract}
The existing discourse on leftist movements in post-Soviet countries characterizes them as weak and isolated. This research analyzes the case of Lithuania, which has had parliamentary left parties since the democratic transition. Despite this, a new leftist movement recently began to emerge. Therefore, I answer the question, how can we explain the emergence of new leftist political groups in the context of a continued prominence and authority of the "old" left in the Lithuanian government? I analyze the case on several levels. The macro-level analysis is based on the European Value Study (EVS) 3rd pre-release of 2017 data, while for meso/micro-level analysis I conducted 8 interviews with the members of the new leftist movement. The research reveals that a precarious society was formed by those who lost out in the democratic transition. The opportunity for the leftist movement to arise was due to a sense of disappointment stimulated by the long-lasting inefficiency of political parties and their inability to deal with precarious conditions in the country. The new leftist movement was formed recently because of the frustrations of the first post-Soviet generation, rising from the discrepancy between dominating class-based capitalist politics and social issues, including identity politics, which stimulated the search for alternative explanations of the socio-economic structure. Moreover, because of the nature of this generation, the new leftist movement is dual -- an anti-austerity-care movement, fighting not only for the improvement of the precarious conditions they are facing but also taking care of the most vulnerable ones and thus creating a more inclusive and equal democracy.
\end{abstract}

Keywords: democratic transition, post-soviet civil society, first post-soviet generation, anti-austerity movements, care movements

\section{INTRODUCTION}

The emergence of leftist social movements in the post-Soviet space is considered to be a complicated phenomenon. Analysis of this topic is usually focused on the study of mechanisms through which leftist movements are repressed and then isolated (Piotrowski, 2005; Abăseacă and Piotrowski, 2018; Cisar, 2013). However, in my research I will ask the difficult and often avoided question: what kind of circumstances allow the leftist social movements to arise and be visible in post-Soviet countries?

The Baltic States are pictured as pioneers of the independence that wanted to break away from the Soviet Union and to eliminate the Soviet legacy as soon as possible (Piotrowski 2015). Indeed, after the collapse of the Soviet Union, the political focus in the Baltic States turned anti-socialist and after the restoration of independence stayed central-right; however, this did not occur in all three states entirely. In Lithuania, the first president after the restoration of independence, Algirdas Brazauskas, was the former head of the Lithuanian Communist Party; and 
the Democratic Labor Party, which mainly consisted of former members of the Communist Party, won the first election (and got 73 places out of 141) (Smith-Sivertsen, 2010). People tended to vote for the candidates they knew for years and expected to retain the economic benefits that they had enjoyed (Okulicz-Kozaryn, 2014).

Despite the presence of the left in Lithuanian government, the alternative leftist movement started to organize in 2016. People took part in protests against the new Labor Code, created the "Life is Too Expensive" collective, started to print broadsheets and organize various actions to address the exploitation of workers. Simultaneously, the social center, called "Emma", was opened where readings of feminism, Marxism, underground music nights, screenings, and discussions were organized. Activists from the informal movement "Life is Too Expensive" founded an independent trade union "May 1st" in 2018. They also registered a formal leftist media platform "Life is Too Expensive" in 2019. This way a part of the broad informal movement became formalized while also carrying on its name and ideals. In 2018 the student movement "Scream" at Vytautas Magnus University (VMU) was created and soon established connections with the aforementioned trade union and the leftist group. These groups supported and encouraged participation in major 2018-2019 protests, marches and strikes.

Therefore, the question of this research is: How can we explain the emergence of new leftist political groups in the context of a continued prominence and authority of the "old" left in the Lithuanian government?

The needs of the electorate to keep the social benefits and economic security from the Soviet system were not satisfied by the elected leftist party. In the 2016 elections, the Lithuanian Social Democratic Party lost their previous recognition in society (in 2012 they got 37 seats in Parliament, while in 2016 only 17). This opened room for discussion about the weakening of the social-democratic tradition in the country (Laucius, 2004) and brought attention to the dissatisfaction of the electorate. According to a 2019 survey, about $60 \%$ of the population does not trust the Lithuanian Parliament and parliamentary parties, showing that the trend of disappointment is a longlasting phenomenon (Eurobarometer). Without the trust of the electorate, parties in Lithuania are not able to stay in power for long. Such a situation, when the government is not able to build trust and the ideological path of an alternative (representative) party is not clear or satisfying enough, provides an opportunity for new political actors to rise, in this case, on the political left.

There are several theoretical explanations in political science which would guide my discussion of the emergence and specifics of leftist movements in the post-Soviet space. First is the political opportunity theory by Sidney Tarrow (2011). He puts forward the necessary conditions for a successful political opportunity to arise. Most important for this research is an increased access to power. The Lithuanian case suggests that the left-wing electorate was always there, however the trust in the existing parties had broken. Therefore, there was an opportunity for the new leftist social movements to emerge as an ideological alternative to the existing social democratic party. Thus, Tarrow's framework will be useful to discuss the context in which new leftist social movements in post-Soviet space appeared.

To explain how the political opportunity formed in this specific regional context I use Ronald Inglehart's (2008) theory of silent revolution in the light of Butler's (1997), Fraser's (1997; 2013), and Moran's (2014; 2020) critique of the subject. Inglehart suggests that in economically developed Western societies, generations born after the Second World War are shifting towards non-material values. Applying his theory to the post-Soviet space we can see that the progress of economic development is visible in several countries; however, the shift is not holistic, since in many of these countries, material living conditions require improvement. Democratization processes in Baltic states allowed the new generation to socialize in a liberalized context and to acquire, as Inglehart would suggest, "non-material" values. In other words, material insecurity together with socio-cultural modernization created a generation concerned about both material and non-material issues. This generation is forming the new left movement. However, many authors have been critical of the understandings perpetuated by Inglehart and others that material concerns have been replaced by non-material concerns. Instead, Butler (1997), Fraser (1997; 2013) and Moran $(2014 ; 2020)$ have argued that even apparently 'non-material' issues are rooted in material conditions; and that concerns with gender, racialized or other 'identities' cannot be treated as wholly lifestyle or cultural issues, divorced from the political economy of capitalist societies. Material conditions may arise in and shape various social issues, which afterwards may maintain the order of the economic system. In other words, the existence of social inequalities based on gender and race derive from material conditions in capitalist societies and the presence of these inequalities allows capitalist societies to function and maintain their class-based order. Therefore, the transition in post-Soviet space is not from material to non-material values, but from class-based reproductive politics and consciousness to a recognition and addressing of social issues, including identity politics. Moreover, the Baltic states, in restoring their independence, accepted the neoliberal model of economy which centers on the free market and its maintenance as the main goal. Thus, the social issues discussed above became even more visible in this context. So, the new generation manifests itself as pioneers of the leftist social movement, which is grappling with the complex interplay of social issues, including of identity and environment, with material conditions. 
A further reason for the political opportunity to arise and its specifics take shape can be developed from Donatella della Porta's (2017) research. She analyzed social movements in Southern Europe and noticed that after the Great Recession in 2008, the livelihood of a large part of society became precarious. People lost their previous security and were disappointed. These feelings encouraged some to turn radical and form anti-austerity movements, demanding greater equality and inclusion in society. These goals are also components of a more representative democracy and therefore such movements aimed to eliminate precariousness by improving their democratic regimes (della Porta, 2015). This theory can be used to explain the emergence of the new leftist social movements in Eastern European context as well, because the disappointment and precarious conditions persisted after the transition period (Zilinskiene and Ilic, 2018; Milanovic, 1995). However, there are several points to add. First, not everybody turns radical and forms coalitions. A lot of people try to keep their disappointment to themselves and act on an individual level. The grievances they experience force them to isolate themselves from collective action because they fail to meet the social norms or have psychological problems (Santos, 2020). The disappointment of Lithuanian society is represented by the high percentage of distrust in governmental institutions ${ }^{1}$. However, this disappointment is publicly expressed only by some trade unions becoming active after the 2008 crisis period (teachers', doctors', agricultural workers', and drivers' trade unions, which organized strikes periodically). Meanwhile, the problems of other less prominent or prestigious sectors were not able to surface. Such conditions, however, can foster a sense of solidarity based on empathy, where people who do not directly benefit from union membership form movements to share their resources with the most vulnerable and those who are not represented in the political arena. Felipe Santos (2020) refers to these movements where collective action is based on assistance and empathic solidarity as care movements. Therefore, della Porta's idea can be revised when talking about post-Soviet countries and the consequences of their democratic transition by complementing it with the theory of care movement.

The case of Lithuania demonstrates that declining trust in existing social democratic parties can open up opportunities for new leftist groups to mobilize. Therefore, we must reconsider the existing consensus on postSoviet civil society and its ideological stances. This study will seek to explain the emergence of leftist social movements: the opening of the political structure for opportunities to arise, the nature of social support they receive, their ideology and framing. Thus, I will be using the three previously discussed theoretical concepts to analyze the subject of my research: declining trust in the existing leftist parties; the shift from the reproduction of class-based consciousness and politics towards social issues and identity politics; and the precariousness of those on the losing end of democratic transition.

The research hypotheses are:

H1: Disappointment based on the inefficiency of ideologically similar political parties stimulates the emergence of alternative political powers.

H2: Precarious conditions stimulate the survival of materialistic concerns in the post-Soviet generation.

H3: Socio-cultural modernization leads to the growth of importance of social issues in the post-Soviet generation.

H4: Discrepancies between the dominant capitalist class-based politics and social issues stimulates a questioning of the existing socioeconomic structure.

The paper is structured in the following way. In the first section the shortened history of the new left movement in Lithuania will be discussed by revealing the national situation and existence of disappointment in the main political parties. The second section presents an analysis of the reproduction of material deprivation through the generations. Third section has two parts. In the first part, the impact of the socio-cultural modernization for the first post-Soviet generation is presented, while the second part discusses the growth of importance of social issues and identity in the first post-Soviet generation. Also, the interplay between dominating capitalist class-based politics and social issues is presented in this section, which leads to a discussion of the creation of the new leftist movement in Lithuania. In the last section the nature of the new left movement is discussed, revealing its duality: it is an antiausterity movement and also a care movement.

\section{METHODOLOGY}

This study combines qualitative and quantitative research methods. For the macro level analysis, I use the $3^{\text {rd }}$ pre-released European Values Study (EVS) 2017 data. It includes integrated and national datasets. The fieldwork in Lithuania was conducted in 2018. I analyze this data using the SPSS quantitative data analysis program. I calculate descriptive statistics and proportions for each generation to understand what percentage of each generation holds

${ }^{1}$ According to the 2019 survey, about 60\% of the population does not trust the Parliament and the Parties (Eurobarometer).

(C) 2021 by Author/s

$3 / 16$ 
certain values. For this reason, I compare the last Soviet generation and the first post-Soviet generation. I define the last Soviet generation as those born, socialized, entering adulthood in Soviet Lithuania (born 1961-1970). The first post-Soviet generation are those born and socialized in independent Lithuania and who are now entering adulthood (born 1991-2000). The generations between these two periods are considered to be the transition generations since they were socialized and entered adulthood during the transition period and were therefore affected by the unstable political and economic situations of the time.

Since the macro level data shows the emergence of alternative political action and increasing differentiation of economic values, the micro/meso analysis focuses on the new left movement. The movement is primarily organized by the representatives of the first post-Soviet generation and focuses on improving the material conditions without excluding social issues and identity politics. For the micro/meso level analysis I conducted 8 semi-structured in-depth interviews with the representatives of the new left movement from three different but inter-related organizations. These organizations are the leftist media platform "Life Is Too Expensive", the trade union "May 1"s", and the student movement "Scream". In the following sections I am going to present the analysis of EVS data and dive deeper into the formation of leftist organizations by testing my hypotheses.

\title{
DISAPPOINTMENT AS A WINDOW FOR A NEW POLITICAL POWER - THE LEFT IN TRANSITION
}

In this section the shortened history of the alternative (new) left movement in Lithuania will be presented. It will be discussed by highlighting the moments of opportunities which emerged from the political situation in the country. So, the first hypothesis that the disappointment based on the inefficiency of ideologically similar political parties stimulates the emergence of alternative political powers will also be tested in this section. At the end of the section, I will also discuss possible pathways for the future of the movement.

First, it is important to mention several pre-existing activities, gatherings, and communities, which formed and shaped the emergence of the new left movement. The following is a description of the context in which the new left emerged:

\begin{abstract}
"Since the late Soviet era, there have been those radical leftists who oppose the authoritarian system and want libertarian communism. The need has always been there, only fragmented, and subcultural. The punk movement can be attributed to this. Punk rockers emerged from the basement and staged a protest in 1991 against militaristic laws. In the 90s it was difficult to get together, because then we had to endure and wait for capitalism to bring happiness. (...) In 2005 anarchija.lt appeared. The people who wrote there were cultural anarchists. That year saw the emergence of the grassroots movement on the issue of public spaces. The Free University was founded in 2008. NK95 was the voice of academics that paved the way for LGBT people. It showed that there is a great deal of left-wing thought in academia." (Informant 5)
\end{abstract}

However, these activities never solidified into a long-lasting movement, which would be characterized by officially registered organizations and those working towards the recognition of a new left movement in the country. This citation represents how people gathered for the first actions of the new left movement:

"It was first the International Free Speech movement, which operated on the basis of a creative workshop. There we worked on our own expression, enabling the expression of others. (...) And then I joined the organizers of the Free University, where people were clearly more left-wing. (...) The Free University was founded in response to educational reforms. It was an idea that you could create a free education, create your own lectures, and invite people, and at the same time create a certain discussion space for certain people. Here I met people on the left, I think they were also gathering at the time, but were not working on inclusive activism. But then a certain collective was born out of it, which was engaged in the setting up autonomous spaces, the protests of organizations on various topics, and which understood itself as a certain collective of people. It was the Solidarity Network that was designed to help workers who have suffered at work or those who tend to fight for better pay (...). In 2016, there was resistance to high prices (...) which were converted from litas to euros (...). There were many groups and small protests all over Lithuania, around 20 events, and then we joined the Kaunas group, and with these people, we organized a march together, and the one in Kaunas was the most successful one in Lithuania. And then I suggested that we do a wider assembly, the proposal was to organize a protest against the labor code. The occupation took place in the City Garden in Kaunas, later in Kudirka Square in Vilnius. And then that movement was called "Life Is Too Expensive."' (Informant 6) 
In 2016 a new Parliament was elected. In 2015, Lithuania joined the Eurozone and prices immediately started to rise. In 2016 there was an explosion of disappointment caused by the realization that entering the EU would not result in better life conditions. Additionally, as we can see from the citation above, there were also other disappointments and disagreements with the political decisions (educational reform, exploitative new labor code), which enabled people to gather and demand change. It was an opportunity for these leftist groups to unite for action. Especially when the only "left" party, the Social Democratic Party, received significantly fewer places in Parliament than usual. However, the new left clearly state that they offer an alternative to the existing Social Democratic Party:

"These people had a political influence that was formed and sustained under the rule of the Soviet apparatus. They remained recognizable as a force from the former system and were able to stay." (Informant 6)

"[We would like to be] an alternative not within the framework of the Social Democrats but an alternative to them, the pressure on the Social Democrats to become Social Democrats." (Informant 2)

The Social Democratic Party is criticized because they do not introduce progressive programs and most of their members understood communism as it was understood in the former system. The alternative to this is a social movement without a definite goal to become a political party and to formalize their position at the level of parliamentary politics. Although it is not a goal of the majority, some members are thinking about standing as candidates in the municipal elections.

Since 2016 the movement has been growing, and it has since been formalized. So now "Life is Too Expensive" became an official leftist media outlet and the trade union "May 1st" was formed to solve the problems of labor exploitation. Meanwhile, the social center "Emma" offered a place where gatherings and events of the previously mentioned organizations could take place:

""Life Is Too Expensive" was an informal organization in which employees helped each other in some way to demand the elimination of injustices. The newspaper "Life Is Too Expensive" was printed for different sectors of workers. That informal network seemed suspicious to the workers, and the press added that the Lithuanian left was probably representing Russian interests. It was decided to establish an official organization, which led to the formation of the "May 1st" trade union. The newspaper was replaced by the "Life Is Too Expensive" page, which was registered as an official left-wing media platform.” (Informant 7)

"The purpose of (Emma) is (to provide space) for social activities, film screenings, lectures, concerts, gatherings, meetings of the same organizations May $1^{\text {st }}$ and Life is Too Expensive. There are people who are (legally) in charge of the space, participate in activities, go to meetings" (Informant 6).

The presence of "May 1st" and "Life is Too Expensive" and their development of leftist discourse influenced another political movement and trade union to emerge. It partly shaped the emergence of the student movement "Scream" and the revival of the trade union in Vytautas Magnus University:

"During the party at Emma's social center we were discussing student representation and lost our patience (...) it had an impact because looking at their activities, you realized that it is possible to form an organized network because they already had experience and [therefore] some of the people were invited to the "Scream" organizational group." (Informant 5)

The members of the student movement "Scream" do not tend to conclude that their movement formed as a result of "Life Is Too Expensive" or the activities at social center "Emma"; however, these played an important role. The idea to form a student movement came up during a party in the social center and some members belong to more than one of these organizations.

The main goals of the student movement "Scream" is the empowerment of students because the present representative organ, the Student Union, is not perceived to be functioning as a voice of students. Therefore "Scream" emerged as an alternative to the non-functioning and/or bureaucratic Student Unions at Vytautas Magnus University and Vilnius University:

"[The biggest achievements of the Scream are] the resolution to support the teacher's community, because it was rejected a year ago. This is a development of discourse. Also, students got involved in these issues and protests. Last thing, the change of Vytautas Magnus University's Student Union, as members of the Scream have appeared. We started to constantly criticize and push for change, so the Student Union started to listen, they are starting to do what it must do, due to this pressure. (...) 
[However], the VMU Student Union hinders some decisions that are made in the Student Parliament, because it was initiated by the members of the Scream. Therefore, it is the only way to win a majority election next year" (Informant 4).

The emergence of the "Scream" is an example of where the new left movement is going:

"There is a need for as many separate movements as possible to cover their own areas of interest and then to form a coalition" (Informant 2)

In general, the movement is planning to create a coalition of future leftist organizations and movements by establishing a well-recognized leftist political structure. In the near future, the plan is to strengthen the " 1 st of May" trade union, together with the "Life Is Too Expensive" left media, and to continue growing the student movement "Scream" to get as many votes as possible in future elections of the Student Parliament in Vytautas Magnus University.

$\mathrm{H} 1$ was confirmed in this section. Disappointment, rising from the perceived inefficiency of the political parties to deal with precarious conditions, is causing a decrease in political identification with the Social Democratic Party. However, this allows alternative political powers to emerge, such as a new leftist movement.

\title{
REPRODUCTION OF MATERIAL CONDITIONS
}

In this section I will discuss the fact that financial problems were of frequent concern for the last Soviet generation. However, even after the democratic transition the situation improved, but not drastically and the financial hardships concentrated in the less privileged social groups. This environment stimulates the reproduction of concerns about material conditions in the first post-Soviet generation. So this section will test the $2^{\text {rd }}$ hypothesis, which states that precarious conditions stimulate the survival of material concerns in the first post-Soviet generation.

Interview analysis revealed that almost all informants' parents experienced financial hardships, job loss and difficulties in finding new employment, before and during the transition period or after the Great Recession. This was happening despite the fact that in most cases, one or both parents had higher education degrees:

\begin{abstract}
"It was difficult, and they could not afford much, and that stress of survival and constant work and struggle was a common motive in their lives (...) they were both studying in a polytechnic institute, where they met (...) it was very difficult because they worked several jobs at once, a little sister (was already born) and they themselves were very young. And everything changed with the restoration of independence, that whole transition that ... there were a lot of direct sales (...) my dad found a job offer at a direct sales company" (Informant 1)
\end{abstract}

"My mother was working in the Bazaar, my father was involved in illegal activities, smuggling of goods or machine parts. When I was little, my parents divorced, and my mother's financial situation was very bad. (...) she has a university degree in economics" (Informant 4)

"Dad is a bureaucrat. He feared he would lose his job due to redundancies in 2008" (Informant 5)

Having a university degree did not help these families to secure good, high-paying jobs. Instead, they were working several jobs which were not prestigious or were taking on illegal positions and activities. However, hardship cannot be unequivocally attributed to the transition period. For some families this was the point where their situation improved. For others, economic hardship was caused not only by the unstable situation in the country but also by the circumstances of their private lives, such as having children or getting divorced and being a single parent in a context of a materially deprived society.

These stories confirm that economic hardship and financial pressures were present in most of the families. However, even if the children were protected from these problems, they faced it in other environments. Experiences in the family or in society formed a perception among informants that a lot of people in Lithuania are facing economic hardship, in most cases this included informants' families. In 2005, $41 \%$ of the population was at risk of poverty or social exclusion (Eurostat 2020, Appendix 1). The lowest percentage (27\%) was in 2014. The latest data of 2019 has the figure at $28 \%$. When around $30 \%$ of the population is balanced on the edge of poverty or social exclusion, a feeling of insecurity about life and the material situation is felt not only for those $30 \%$ but also those in wider society. Moreover, the unemployment rate in Lithuania is much more unstable compared to other post-communist states such as Poland, Hungary and Romania, and also Western European countries such as Germany, Sweden, and the United Kingdom (Eurostat 2020, Appendix 2). High peaks, with 17.5\% of the population unemployed after crisis periods (2001 and 2010) suggests that the labor market is very sensitive to 
Table 1. Signing a petition

\begin{tabular}{|l|c|c|c|c|}
\hline \multirow{2}{*}{ Position } & \multicolumn{4}{|c|}{ Age/N } \\
\cline { 2 - 5 } & $\mathbf{1 8 - 2 7}(\mathbf{1 8 7 )}$ & $\mathbf{2 8 - 3 7}(\mathbf{1 7 7 )}$ & $\mathbf{3 8 - 4 7}(\mathbf{2 0 8 )}$ & $19.2 \%$ \\
\hline Have done & $18.7 \%$ & $21.5 \%$ & $52.9 \%$ & $14.8 \%$ \\
\hline Might do & $60.4 \%$ & $53.1 \%$ & $27.9 \%$ & $51.7 \%$ \\
\hline Would never do & $20.9 \%$ & $25.4 \%$ & $33.5 \%$ \\
\hline
\end{tabular}

Table made by the author, using data from The European Values Study, 2017

recessions. More recently, the rate of unemployment has reached around 5-6\% (in 2019). This situation creates a sense of instability and insecurity.

Concerns about financial problems are imprinted in the discourse and consciousness of the society; however, for the first post-Soviet generation these concerns were activated when they became students, entering the labor market, relying less on their parents/family, and experiencing the precarious conditions themselves:

"The job issue is that when you reach a certain age, you need to start working (...) and you start to see that somebody was fired because of [sexual] orientation or (you are) paid a lower salary because you are a woman" (Informant 6)

"I did not have people in my immediate environment who faced a difficult financial situation or discrimination, but over the years I met such people. I have friends who are gay.... and the experiences I had only read about, they confirmed. (...) for me then it became more personal and less abstract (...) [I have] a much greater appreciation of material matters now. It is only because I entered adulthood and began to work and realized that work sucks. Despite having a decent position, it drains a lot of energy from you. If my job is frustrating because I don't have time for personal life, then how should people who are doing repetitive, routine work feel, and the manager behaves like you're a replaceable robot?” (Informant 3)

"Looking at the social space, society is very angry and dissatisfied, it accumulates anger and simply burns with it because it experiences humiliation at work (...) I, as a student, also feel precarious because I have no guarantees for my future" (Informant 5)

$\mathrm{H} 2$ was confirmed in this section: material concerns were reproduced in the first post-Soviet generation through their family situation and simultaneously through the observation of a precarious society. However, these concerns were activated and became respondents' primary concern only when they started to enter the labor market and adulthood.

\section{UNIQUE TRAITS OF THE FIRST POST-SOVIET GENERATION}

\section{Impact of Socio-cultural Modernization}

The change of the political regime and the accompanying socio-cultural liberation had its impact on civil society in Lithuania. Socialization, in the context of a more liberalized discourse and understanding of civil rights and freedoms, shaped civil activism even in the transition generations. But the change is more evident when we compare the first post-Soviet and the last Soviet generations. In this section I am going to reveal the shift in civil society towards different and more open modes of political action, which will later help us to test the $3^{\text {rd }}$ and the $4^{\text {th }}$ hypotheses.

The analysis of the 3rd pre-released European Values Study (EVS) 2017 data reveals that the post-Soviet generation is or tends to be more politically active than their parents' generation. This growing tendency can already be observed in the transition generations (Table 2). The first post-Soviet generation has signed more petitions $(18.7 \%)$ than their parents $(14.8 \%)$ despite their young age. Moreover, they are much more open to forms of political activism than previous generations. The proportion of those who might sign a petition in the first postSoviet generation is $60.4 \%$, while in the last Soviet generation it is $51.7 \%$. The tendency increases in the transition generations. Around 53\% might sign a petition. Also, the first post-Soviet generation is less reluctant than previous generations. $20.9 \%$ of the first post-Soviet generation would never sign a petition, while the last Soviet generation is more critical with $33.5 \%$ of those who would never sign. A slow shift towards being more open to petitions is visible by observing the transition generations (Table 1).

Similar tendencies can be observed in joining boycotts (Table 2), lawful demonstrations (Table 3) and unofficial strikes (Table 4). However, there is a difference in the level of participation in these actions. The first post-Soviet generation has smaller numbers (boycotts 4.4\%, demonstrations $4.2 \%$, strikes $1.1 \%$ ) than the last Soviet generation (boycotts 6.9\%, demonstrations 7.8\%, strikes 1.8\%). This tendency can be explained by the fact 
Table 2. Joining boycotts

\begin{tabular}{|l|c|c|c|c|}
\hline \multirow{2}{*}{ Position } & \multicolumn{4}{|c|}{ Age/N } \\
\cline { 2 - 5 } & $\mathbf{1 8 - 2 7}(\mathbf{1 8 3})$ & $\mathbf{2 8 - 3 7} \mathbf{( 1 6 7 )}$ & $\mathbf{3 8 - 4 7}(\mathbf{2 0 5})$ & $\mathbf{4 8 - 5 7 ( 2 3 1 )}$ \\
\hline Have done & $4.4 \%$ & $6.6 \%$ & $10.7 \%$ & $6.9 \%$ \\
\hline Might do & $62.3 \%$ & $54.5 \%$ & $51.2 \%$ & $48.5 \%$ \\
\hline Would never do & $33.3 \%$ & $38.9 \%$ & $38.0 \%$ & $44.6 \%$ \\
\hline
\end{tabular}

Table made by the author, using data from The European Values Study, 2017

Table 3. Attending lawful demonstrations

\begin{tabular}{|l|c|c|c|c|}
\hline \multirow{2}{*}{ Position } & \multicolumn{4}{|c|}{ Age/N } \\
\cline { 2 - 5 } & $\mathbf{1 8 - 2 7}(\mathbf{1 8 9})$ & $\mathbf{2 8 - 3 7} \mathbf{( 1 7 3 )}$ & $\mathbf{3 8 - 4 7 ( 2 0 6 )}$ & $\mathbf{4 8 - 5 7 ( 2 4 5 )}$ \\
\hline Have done & $4.2 \%$ & $2.9 \%$ & $9.7 \%$ & $7.8 \%$ \\
\hline Might do & $65.1 \%$ & $56.1 \%$ & $54.4 \%$ & $55.1 \%$ \\
\hline Would never do & $30.7 \%$ & $41.0 \%$ & $35.9 \%$ & $37.1 \%$ \\
\hline
\end{tabular}

Table made by the author, using data from The European Values Study, 2017

Table 4. Joining unofficial strikes

\begin{tabular}{|l|c|c|c|c|}
\hline \multirow{2}{*}{ Position } & \multicolumn{4}{|c|}{ Age/N } \\
\cline { 2 - 5 } & $\mathbf{1 8 - 2 7}(\mathbf{1 7 4})$ & $\mathbf{2 8 - 3 7} \mathbf{( 1 6 7 )}$ & $\mathbf{3 8 - 4 7}(\mathbf{1 9 0 )}$ & $\mathbf{4 8 - 5 7 ( 2 2 0 )}$ \\
\hline Have done & $1.1 \%$ & $0.6 \%$ & $1.6 \%$ & $1.8 \%$ \\
\hline Might do & $50.0 \%$ & $35.3 \%$ & $39.5 \%$ & $30.9 \%$ \\
\hline Would never do & $48.9 \%$ & $64.1 \%$ & $58.9 \%$ & $67.3 \%$ \\
\hline
\end{tabular}

Table made by the author, using data from The European Values Study, 2017

Table 5. Satisfaction with the political system

\begin{tabular}{|l|c|c|c|c|}
\hline \multirow{2}{*}{ Position } & \multicolumn{4}{|c|}{ Age/N } \\
\cline { 2 - 5 } & $\mathbf{1 8 - 2 7} \mathbf{( 2 0 0 )}$ & $\mathbf{2 8 - 3 7} \mathbf{( 1 9 0 )}$ & $\mathbf{3 8 - 4 7} \mathbf{( 2 2 1 )}$ & $\mathbf{4 8 - 5 7 ( 2 6 1 )}$ \\
\hline Rather dissatisfied & $37.5 \%$ & $44.2 \%$ & $39.4 \%$ & $49.4 \%$ \\
\hline Rather satisfied & $41.0 \%$ & $33.8 \%$ & $43.4 \%$ & $32.9 \%$ \\
\hline Neutral & $21.5 \%$ & $22.1 \%$ & $17.2 \%$ & $17.6 \%$ \\
\hline
\end{tabular}

Table made by the author, using data from The European Values Study, 2017

Table 6. Voting in national elections

\begin{tabular}{|l|c|c|c|c|}
\hline \multirow{2}{*}{ Voting } & \multicolumn{4}{|c|}{ Age/N } \\
\cline { 2 - 5 } & $\mathbf{1 8 - 2 7 ( 1 9 0 )}$ & $\mathbf{2 8 - 3 7 ( 1 9 2 )}$ & $\mathbf{3 8 - 4 7 ( 2 2 6 )}$ & $\mathbf{4 8 - 5 7 ( 2 6 9 )}$ \\
\hline Always & $12.6 \%$ & $21.4 \%$ & $25.7 \%$ & $36.1 \%$ \\
\hline Usually & $45.8 \%$ & $65.1 \%$ & $67.3 \%$ & $58.4 \%$ \\
\hline Never & $41.6 \%$ & $13.5 \%$ & $7.1 \%$ & $5.6 \%$ \\
\hline
\end{tabular}

Table made by the author, using data from The European Values Study, 2017

that the first post-Soviet generation has not had many opportunities to participate in such actions due to their young age, while the last Soviet generation could participate in the political demonstrations against the Soviet regime. Despite that, the first post-Soviet generation is more willing to participate in these actions (boycotts 62.3\%, demonstrations 65.1\%, strikes 50.0\%), compared to the last Soviet generation (boycotts $48.5 \%$, demonstrations $55.1 \%$, strikes $30.9 \%$ ) and the transition generations (Tables 2, 3, 4). The first post-Soviet generation is also less critical of the discussed actions, compared with the previous generations (Tables 2, 3, 4).

However, despite the willingness to participate in the contentious politics of the first post-Soviet generation, they report a much greater satisfaction with the political system than previous generations. $41 \%$ of them are rather satisfied and 37.5\% are rather dissatisfied (Table 5).

Furthermore, the first post-Soviet generation is the least active in national elections (only $12.6 \%$ always participate and $41.6 \%$ stated that they never participate (Table 6)). This can be explained by the fact that those who were 18-20 in 2018 were not able to participate in an election, since they were not 18 when the last national election took place (in 2016). However, the tendency of declining turnout in national elections is also visible in previous generations. Moreover, the recent parliament election turnout in 2020 shows that $39.1 \%$ of those, born between 1991-2000 participated in the election, in comparison with 48.1\% of those born between 1975-19562. Even if the year range of the former does not match with the last Soviet generation discussed in this research, the tendency suggests that society is becoming less politically engaged with each generation regarding national politics and therefore tends to look for alternative ways of political expression (such as petitions, demonstrations or strikes).

${ }^{2}$ Data from The Central Electoral Commission of the Republic of Lithuania

$8 / 16$

(C) 2021 by Author/s 
Table 7. Belonging to environment, ecology, or animal rights movement

\begin{tabular}{|l|c|c|c|c|}
\hline \multirow{2}{*}{ Belonging } & \multicolumn{4}{|c|}{ Age/N } \\
\cline { 2 - 5 } & $\mathbf{1 8 - 2 7}(\mathbf{2 0 9})$ & $\mathbf{2 8 - 3 7 ( \mathbf { 1 8 6 } )}$ & $\mathbf{3 8 - 4 7}(\mathbf{2 2 1})$ & $\mathbf{4 8 - 5 7}(\mathbf{2 6 7 )}$ \\
\hline Yes & $2.4 \%$ & $2.2 \%$ & $2.3 \%$ & $1.5 \%$ \\
\hline No & $97.6 \%$ & $97.8 \%$ & $97.7 \%$ & $98.5 \%$ \\
\hline
\end{tabular}

Table made by the author, using data from The European Values Study, 2017

Table 8. Important in a job: good pay

\begin{tabular}{|l|c|c|c|c|}
\hline \multirow{2}{*}{ Important } & \multicolumn{4}{|c|}{ Age/N } \\
\cline { 2 - 5 } & $18-27(210)$ & $28-37(193)$ & $38-47(230)$ & $48-57(268)$ \\
\hline Yes & $97.6 \%$ & $98.4 \%$ & $98.3 \%$ & $99.6 \%$ \\
\hline No & $2.4 \%$ & $1.6 \%$ & $1.7 \%$ & $0.4 \%$ \\
\hline
\end{tabular}

Table made by the author, using data from The European Values Study, 2017

All in all, socio-cultural modernization after the dissolution of the Soviet Union is evident when observing the data about civil activism in Lithuania. The younger generations are becoming more open to contentious politics, compared to previous generations who were more afraid of it. Moreover, the younger generations are finding new ways of political expression, such as signing petitions.

\section{Between Social Issues and Class Politics: Emergence of Identity Questions and Search for Alternative Explanations}

In the first section it was stated that material concerns are reproduced in the first post-Soviet generation. They are activated when young people experienced precarious conditions upon entering the labor market or when exposed to inequalities or exploitation in their immediate social environment. However, the unique trait of this generation was revealed during the interviews. They are also concerned about social issues and identity-related questions, usually simultaneously or even before being exposed to material issues. Therefore, in this section I am going to test the $3^{\text {td }}$ and the $4^{\text {th }}$ hypotheses of this research, which states that sociocultural modernization leads to the increasing importance of social issues, including identity in the first post-Soviet generation; and that the dominating discourse of class-based politics intersects with these social and identity-based questions. The first post-Soviet generation's rising disappointment and frustration about the socioeconomic system leads to questioning and the search for political alternatives.

To start with $3^{\text {rd }}$ hypothesis, the emergence of identity-related questions is tackled in these experiences:

"LGBT + people are often more sensitive. Those, who did not fit in for a variety of reasons in their communities... To some extent, there are people who have some kind of mental illness or are more sensitive, have anxiety or depression, they may feel another's pain. But it also happens that people come from a bourgeois family and want to help others (...), but they also have some problems of their own." (Informant 6)

"[Interest] in labor relations issues, labor policy stems from discrimination, which has been an important issue for a long time. After [x health problems] I moved to another school where I experienced bullying (...) later it helped me become a more empathetic person (...) sexism, homophobia, xenophobia, contempt for people who have not succeeded in life and the injustice that they are being blamed for their own situation ... It made me sick. (...) (so) in the beginning, social issues and identity politics were more important." (Informant 3)

The growth of the importance of general social issues in the first post-Soviet generation is also confirmed by the data of The European Values Study. First, there is an increased tendency to belong to environmental, ecological and animal rights movements across all generations. However, the highest percentage $(2.4 \%)$ of participation in these movements is in the first post-Soviet generation (Table 7).

Decrease in the importance of material values among members of the first post-Soviet generation is presented in Table 8. When asked how important a good pay is when choosing a job, the first post-Soviet generation valued it the least (2.4\% answered that it is not important, compared with $0.4 \%$ for the last Soviet generation). The importance decreases in younger generations.

Although the shift of interests is visible, it is not drastic. The emergence is happening gradually because it is only the beginning of the changes which started with the transition generation. The process is difficult, because of the presence of class-based discourse and politics - namely, the way the economy and society were structured after the democratic and capitalist transition. This notwithstanding, it is possible to track the increasing importance of social issues and identity politics. 
Table 9. Protect environment versus economic growth

\begin{tabular}{|l|c|c|c|c|}
\hline \multirow{2}{*}{ Position } & \multicolumn{4}{|c|}{ Age/N } \\
\cline { 2 - 5 } & $\mathbf{1 8 - 2 7}(\mathbf{1 7 7})$ & $\mathbf{2 8 - 3 7 ( 1 7 5 )}$ & $\mathbf{3 8 - 4 7}(\mathbf{2 0 3 )}$ & $33.0 \%$ \\
\hline Protect environment & $39.5 \%$ & $36.0 \%$ & $67.0 \%$ & $34.1 \%$ \\
\hline Economic growth & $60.5 \%$ & $64.0 \%$ & $65.9 \%$ \\
\hline
\end{tabular}

Table made by the author, using data from The European Values Study, 2017

The best representation of the shift towards social issues in the younger generations is in Table 9. The respondents were asked which they preferred, to protect the environment or to pursue economic growth. The first post-Soviet generation showed increasing interest in environmental issues $(39.5 \%)$, compared with the previous generations (34.1\% for the last Soviet generation). Even though economic growth still receives more concern, its importance is decreasing (Table 9).

The analysis here confirms $\mathrm{H} 3$, that socio-cultural modernization stimulated the increase of importance of social issues, including identity and environmental issues in the first post-Soviet generation. Returning to the analysis of the personal stories of the interviewees, personal problems (which were social at their core) caused a feeling of injustice among the respondents. They were looking for explanations as to why society is full of discrimination, anger, and inequality:

"[Started] with cultural education, [interest] in punk rock, with the stupid rebellion that was broadcasted in music (...) that something in the world is not OK, that the present is problematic and flawed." (Informant 5)

“After school and after quitting university, I really felt like there was something I fundamentally didn’t like. How life is typically organized in our society ... and somehow that was very intuitive and that led me to look for some conceptual ways to explain the frustration I felt." (Informant 1)

These experiences of "sick society" guided them to look for answers in leftist theory and anarchism. It was usually the academic community or teachers that influenced such directions, but for some it was a personal discovery:

"I started to transform at university, I met some specific communities, I was influenced by the academic community, the social center Emma. I also went abroad to work in the summer, (where) I met people who were quite engaged." (Informant 1)

““'Santara Sviesa” is such an intellectual informal movement in which I also participated a lot. It was there that I met my young friends who were actually on the far left. And through some discussion, I realized that there was something there. It felt good to no longer be an alternative thinker, that opposite thinker who is disliked." (Informant 2)

"I have always had an interest in alternative culture, questioning the norm, pop culture. (...) But I was interested in political theory from the outset (...) [as a teenager] I was impressed by the hippie subculture, such belief in idealism. (...) I discovered and started reading anarchist texts on social media, namely the site anarchija.lt. Then my understanding of capitalism, competition, liberalism began to expand..." (Informant 3)

Anarchism as the primary source of the alternative and radical ideas was mentioned in several interviews. The existence of radical leftist thought was also prominent in the stories of the interviewees. They mentioned academic circles and communities, which have links to Vytautas Magnus University. However, these informal communities were not able to morph into a unified movement that could represent not only their interests but struggles of the entire society:

"“NK95" was the voice of academics that paved the way for LGBT people. It has shown that there is a great deal of left-wing thought in academia, but they have their positions and do not want to risk losing them by taking to the streets. "Life Is Too Expensive" was not out of nowhere, it gradually took some influence from certain people, learned from unfortunate events." (Informant 5)

Previous generations were unable to act. They were limited by the unfortunate situation, where being a leftist was a crime against the state:

"[In the past] thinking left was a crime because some ... tried to legalize leftist political thinking through the courts." (Informant 2) 
"At first, [society] defined our group as anarchists because you know, there could be no communists in Lithuania for a decade. Now, as you know, you can be one. You can use that word. (...) Two prime ministers in a row called the teachers' union protests pro-Russian. And never did this allegation turn out to be true." (Informant 6)

However, these leftist, transitional generations were speaking up in the universities, writing articles, and organizing intellectual gatherings, which were noticed by the first post-Soviet generation. The conditions under which this generation grew up influenced their disappointment. This disappointment, arising from the discrepancy between the reality and the dominating discourse of neoliberal progress, stimulated the organization of the new left movement:

"For a while, this dream worked well and motivated things. The more West, the better, and we just need to try, and it will only get better, just like in the West. But then came the realization and the frustration that this model of competitive, free market and liberal democracy is not a source of prosperity for many, and this dream does not deliver what it promised." (Informant 7)

To put all things together, socio-cultural modernization after the democratic transition influenced the flow of liberal ideas, including new ways of thinking about being different or having alternative opinions. The democratic transition brought not only neoliberalism and the negative consequences of the free market, including inequality and financial hardship, but also the idea that different identities can and should be tolerated as part of an inclusive society. The period when this recognition occurred was the time when the first post-Soviet generation was growing up. They were frustrated by unexplainable feeling that the social and economic system was not working and was in tension with their values. This frustration and disappointment caused the questioning of the socioeconomic system in which they are living and stimulated the search for the alternative explanations of social reality. This led to the formation of the leftist social movement. Therefore, taking the above into consideration, $\mathrm{H} 4$ has been confirmed in this section.

\section{MOVEMENTS OF THE PRECARIOUS SOCIETY: BETWEEN ANTI-AUSTERITY AND CARE}

In previous sections the precariousness of the Lithuanian society was discussed. However, in this section it will be explained in fuller detail with reference to the emergence of the new left movement in Lithuania. The following citation succinctly describes an atmosphere of instability in the country, where the "dream" of a better, neoliberal future was shattered, and people faced economic and social deprivation:

"For older people, that dream never existed, they suffered trauma from the moment of transition. Some say they long for the Soviet era, but they have very specific reasons. They are longing for some stability, work, respect that they do not have now when they are expected to die for something to change in the country. And for the younger generation, this dream turned into emigration. When all your values are focused on the pursuit of the West, it is better for you to go West than to wait for things to catch up here. The 2008 crisis and the switch to the euro were a blow. Even my father, who is a liberal, says it is too expensive for him to live. It seems that recently a lot of sectors have started complaining, so this story that everything is getting better seems to be convincing only in the center of Vilnius." (Informant 7)

The situation described by the interviewee suggests that only a small group of elites share the increasing wealth in Lithuania, while the majority is struggling because of economic and social inequality.

In response to this inequality, is the new left movement an anti-austerity movement, where the precariat is uniting? Or is it a care movement, which empowers the most vulnerable ones? In the previous section, it was argued that the importance of social issues started took root in the first post-Soviet generation; however, material concerns continue to dominate and are reproduced through family experience and experienced directly when individuals enter the labor market. Therefore, this generation is concerned with the complex interplay of material conditions and social issues, identity politics and recognition. This is how the informants describe the overlap of material and social concerns:

"Someone is fired because of his orientation or (someone) is paid a lower salary because she is a woman (...) And through the issue of work all social things can become visible." (Informant 6)

Even though they focus mostly on the material issues, social questions are not left out of the discussion: 
"[When] dealing with trade unions, where there is a labor movement, then there is a tendency to emphasize social solidarity, to introduce feminist, queer considerations." (Informant 7)

Therefore, the movement focuses on social issues, including identity politics, and their relation to material conditions. Moreover, the movement is dual: it is an anti-austerity movement and a care movement. It represents the most vulnerable and plays a role of caring, thus being a movement of the precariat. These citations represent the duality of the movement:

"There were postmen who had problems because their workplace was supposed to be closed. Someone had [our] number and called. This group, which works in one workplace, started talking about working conditions; and then you start to think about what (may be possible) problems, maybe not according to the Labor Code in one way or another. "May $1^{\text {st" }}$ members are now communicating with them further. There is a published article about their working conditions in the post office. Trade union offer free consultations to people, but after consultations, people rarely return or join a union. It's like charity" (Informant 6).

"A group of women from the Lithuanian Railways called us because of unequal salary increases and asked for a consultation. We helped them with that, we advised on labor rights. (...) At the very beginning of the [Corona virus] crisis, there was an informational sheet of workers' rights. [It was informing] that they cannot simply fire you, [it was] warning that you will not sign any documents, or that you can cancel the signed document. It can also be a direct help. We have money in the treasury, if you lost your job, you can take it, the time will come - you will return" (Informant 8).

"When we built the Solidarity Network, there were a lot of students on our side. The point is, to appreciate that you will work in the future, and now you are a student... you may have to work. Those who had already worked were certainly the majority. At that time, you had to be able not to work and sit in the occupation. It's a little harder for a working person to do that" (Informant 6).

First and second citations are illustrative of several situations where the movement acted as a care movement. Students in the Solidarity Network had such resources as time and some additional knowledge to organize the protests and occupations; however, they did this not only to represent the workers but also as a future investment in better working conditions for themselves.

In this section it was revealed that a sense of economic insecurity is common in Lithuanian society. The presence of this discourse, together with precarious economic conditions, stimulated materialistic concerns in the first post-Soviet generation. However, the impact of socio-cultural modernization can also be observed as part of first post-Soviet generation's participation in contentious politics. For example, there has been an increased interest in ecological, environmental, gender and sexual equality issues in younger generations. The discrepancy between their ideals of an equal and inclusive society and the precarious economic conditions they were experiencing created the stimulus to form a movement. In doing so, they sought to deal with problems which concerned their generation as well as the problems facing the most vulnerable groups in wider society. Thus, the movement created by the first post-Soviet generation can be seen as an anti-austerity-care movement.

\section{CONCLUSIONS}

In general, leftist social movements in post-Soviet and post-Communist countries are perceived as repressed and isolated. However, their recent emergence can be traced in Hungary, Poland, and Lithuania. In first two, the rightist government has been dominating for several years, while in Lithuania the leftist parties have been part of the government for a while even though their popularity has been decreasing. Therefore, even if the political context of Lithuania is slightly different, the socio-economic reasons for the emergence of a leftist movement are similar to those in other post-Soviet or post-Communist countries.

In this research I explored the reasons why a political opportunity for the new leftist groups emerged, despite the presence of the left in the Lithuanian government. In other post-Soviet countries, in contrast, leftist parties are small and lack a popular base.

This research was based on the theory of political opportunity, combined with the concept of generational value change. It offers a critique of the concept of silent revolution, stressing the significance material conditions and the emergence of winners and losers during the democratic transition. This theoretical framework explained the emergence of new political players in Lithuania, the reasons why the political opportunity emerged and its specificity, as a response to a precarious society. Social and economic factors combined with political changes created an opportunity for the new leftist movement in Lithuania to emerge. 
All four hypotheses were confirmed by this research. The main political change was decreasing political affiliation, which is tied with low levels of trust and belief in political parties. It emerged from the inefficiency of parliamentary parties in dealing with deep-set, precarious social and economic conditions. Since the existing political parties did not satisfy the needs of the electorate, there was an opportunity for an alternative political power to emerge: the new leftist movement.

One of the reasons the political opportunity formed was revealed by using critique of the concept of silent revolution. Socio-cultural modernization in Lithuania started in the 80s and intensified after the restoration of the independence. Therefore, the first post-Soviet generation was socialized in an environment where the importance of social issues, including identity politics started to grow. Raising social issues worked with and against more traditional class-based politics and led to the search for the alternative explanations of how the socioeconomic system can be re-structured.

The analysis of the winners and losers of the democratic transition revealed that Lithuanian society is facing precarious social and economic conditions. Material insecurity was a common experience for the last Soviet generation. These materialistic concerns of the last Soviet generation were reproduced by the first post-Soviet generation and became activated when they started to enter the labor market.

These three conditions: long-standing precariousness, loss of trust in political parties, and the frustration for the first post-Soviet generation, rising from tension between class-based capitalist politics and social issues are the reasons that the political opportunity for the new left arose.

The research also revealed that the new leftist movement is not only an anti-austerity movement, fighting against inequality and precarious conditions in the country, but also a care movement. This movement mobilized to help not only its members but also to stress the problems of most vulnerable and to empower those who are under-represented. The reasons for this dual aspect of the movement may rise from the essence of the first postSoviet generation, which is the main organizer of the new leftist movement in Lithuania. Their understanding of the complex intersection between material conditions and identity politics stimulates the goal to improve democracy and living conditions in the country. Therefore, they are interested not only in the issues which are significant to them, but also in the struggles of others. In this way, the new leftist movement is trying to eliminate precariousness by creating a more representative and thus more equal democracy.

The theoretical framework, which was adapted to this post-Soviet context, can be applied in research about leftist social movements in other post-Soviet or post-Communist countries to examine the emergence of identity politics after the democratic transition and the impact of precarious economic conditions on the first post-Soviet generation. In addition, this framework can be used to trace the emergence of the leftist social movements in countries such as Hungary, Poland, and the Czech Republic. By applying this framework, the dominant discourse about leftist movements in post-Soviet space and post-Soviet civil society can be challenged.

The research was limited due to its time-frame. Leftist groups from previous decades are not represented here, and their influence is discussed only through the lenses of the new leftist movement. Moreover, the broader picture of political players in the field, such as political right and rightist movements, are not discussed in this research. Thus, several important factors are, no doubt, omitted. Therefore, further research that aims to create a broader picture is recommended.

\section{REFERENCES}

Abăseacă, R., Piotrowski G. (2018). Introduction: radical left in central and Eastern Europe. Constraints and opportunities. East European Politics, 34(1), 1-5. https:// doi.org/10.1080/21599165.2018.1425206

Butler, J. (1997). Merely Cultural. Social Text, 52/53, 265-277. https://doi.org/10.2307/466744

Císař, O. (2013). Post-Communism and Social Movements, in D. A. Snow et al. (eds), Encyclopedia of Social and Political Movements, vol. 3 [pp. 994-999]. London: Blackwell. https://doi.org/10.1002/9780470674871.wbespm481

della Porta, D. (2015). Social movements in times of austerity: bringing capitalism back into protest analysis. Cambridge; Malden: Polity press. http://hdl.handle.net/1814/35684

della Porta, D. (2017). Political Economy and Social Movement Studies: The Class Basis of Anti-Austerity Protests. Anthropological Theory, 17(4), 453-473. https://doi.org/10.1177/1463499617735258

della Porta, D. (2019). Conceptualizing backlash, in Eurozine, June 27. https://www.eurozine.com/conceptualizing-backlash/

Fraser, N. (1997). Heterosexism, Misrecognition, and Capitalism: A Response to Judith Butler. Social Text, 52/53, 279-289. https://doi.org/10.2307/466745

Fraser, N. (2013). Fortunes of Feminism: From State-Managed Capitalism to Neoliberal Crisis. New York: Verso.

Inglehart, F. R. (2008). Changing Values Among Western Publics from 1970 to 2006. West European Politics, 31(12), 130-146. https://doi.org/10.1080/01402380701834747

(C) 2021 by Author/s 
Laučius, V. (2004). Anapus dešinès ir kairès ["Beyond the Right and the Left"], in L. Vladimiras (ed.), Tarp dvieju Prezidento rinkimu: 2002-2004 ["Between the Two Presidential Elections: 2002-2004”] [pp. 122-125]. Vilnius: Demokratinès politikos institutas.

Mannheim, K. (1927/28, repub. 1952). The problem of generations, in P. Kecskemeti (ed.), Karl Mannheim: Essays [pp. 276-322, 22-24 (introduction)]. Routledge.

Milanovic, B. (1995). Poverty, inequality, and social policy in transition economies. Washington, DC: World Bank.

Moran, M. (2014). Identity and Capitalism. London: Sage. ISBN: 978-1-4462-4975-8.

Moran, M. (2020). (Un)troubling identity politics: A cultural materialist intervention. European Journal of Social Theory 23(2), 258-277. https:/ / doi.org/10.1177/1368431018819722

Okulicz-Kozaryn, A. (2014). Winners and Losers in Transition: Preferences for Redistribution and Nostalgia for Communism in Eastern Europe. Kyklos, 67(3), 447-461. https://doi.org/10.1111/kykl.12062

Piketty, T. (1971, 2014). Capital In the Twenty-First Century. Cambridge Massachusetts: The Belknap Press of Harvard University Press. https:/ / doi.org/10.4159/9780674369542

Piotrowski, G. (2015). What are Eastern European Social Movements and How to Study Them? Intersections. East European Journal of Society and Politics, 1(3), 4-15. https:// doi.org/10.17356/ieejsp.v1i3.42

Santos, G. F. (2020). Social movements and the politics of care: empathy, solidarity and eviction blockades. Social Movement Studies, 19(2), 125-143. https:/ / doi.org/10.1080/14742837.2019.1665504

Smith-Sivertsen, H. (2010). The Baltic states, in R. P. Sabrina (ed.), Central and Southeast European Politics since 1989 [pp. 447-472]. Cambridge: Cambridge University Press. https://doi.org/10.1017/CBO9780511803185.024

Tarrow, S. (2011). Power in Movement. New York: Cambridge University Press. 3rd ed. https://doi.org/10.1017/CBO9780511973529

Žilinskienè, L., Ilic, M. (2018). Changing family values across the generations in twentieth-century Lithuania. Contemporary Social Science, 15(3), 316-329. https:/ / doi.org/10.1080/21582041.2018.1516297 


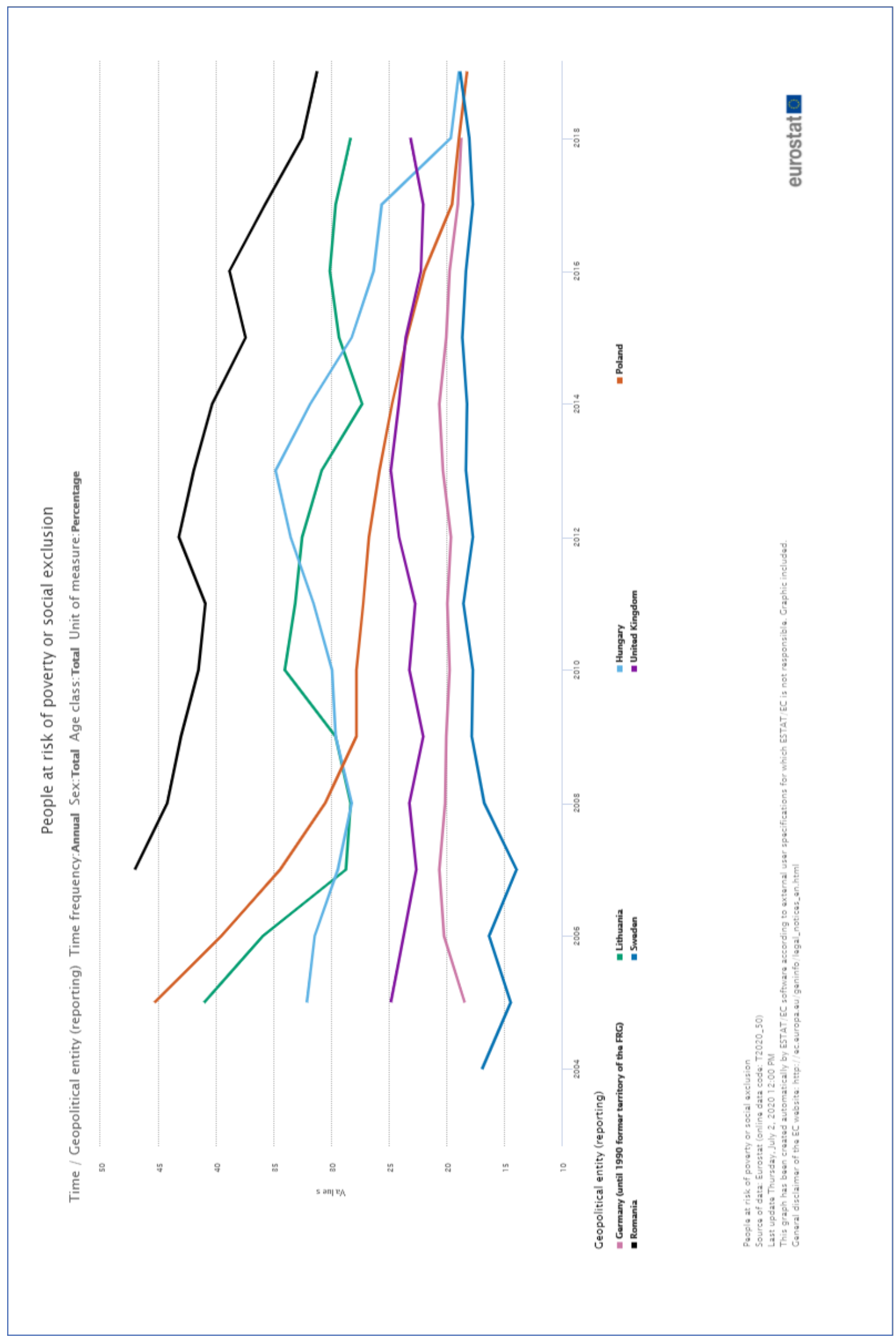

Eurostat (2020). 


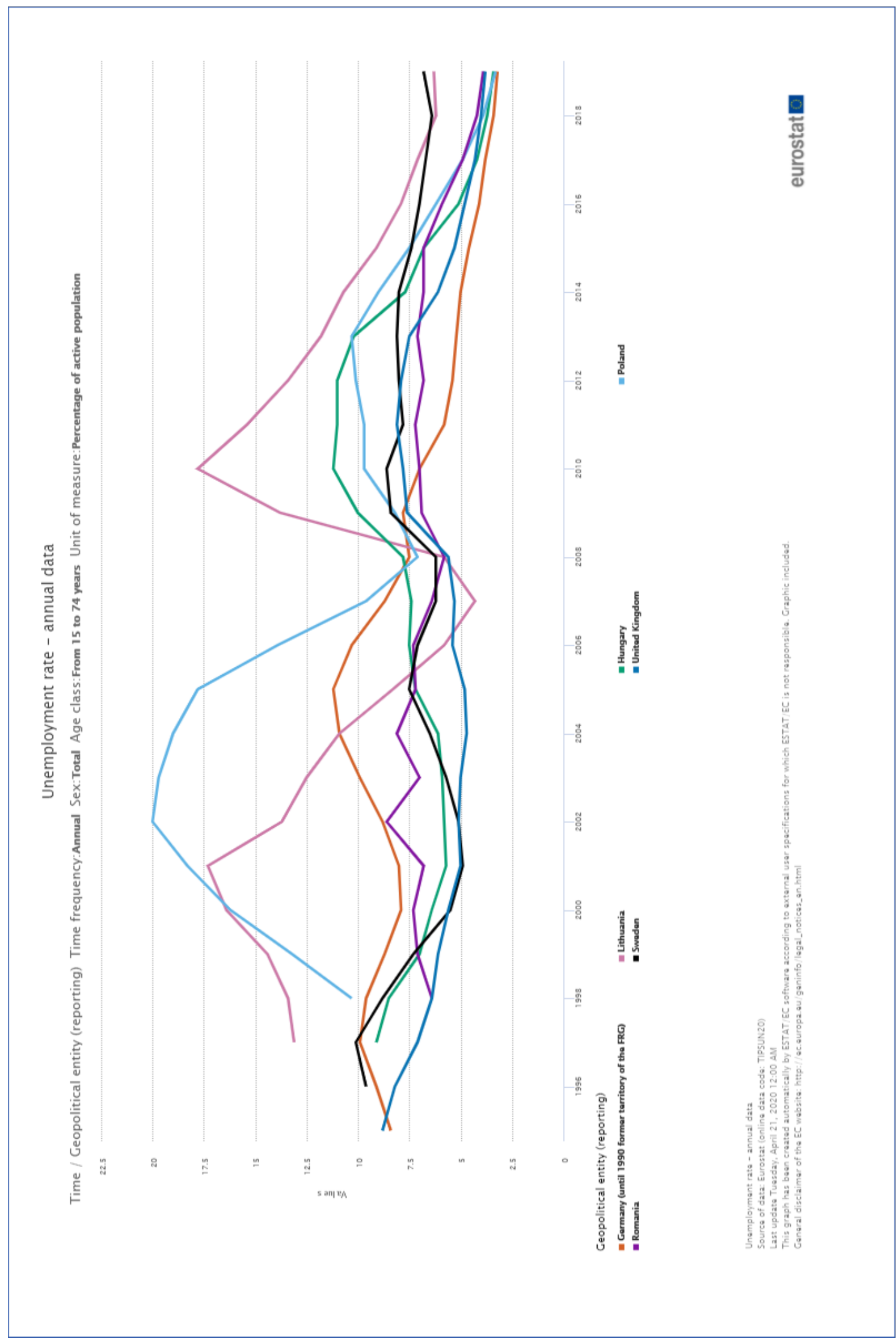

Eurostat (2020). 